\title{
THE USE OF ENGLISH FOR METAPHORICAL EXPRESSIONS IN INDONESIAN SLANG
}

\author{
I Dewa Putu Wijana* \\ Faculty of Cultural Sciences Gadjah Mada University \\ *Corresponding Author Email: idp wijana@yahoo.com
}

This is an open access article distributed under the Creative Commons Attribution License, which permits unrestricted use, distribution, and reproduction in any medium, provided the original work is properly cited.

\section{ARTICLE DETAILS}

Article History:

Received 15 July 2019

Accepted 19 August 2019

Available online 23 August 2019

\section{ABSTRACT}

The more central role played by English in every aspect of human life will directly cause the more extensive influence of this language on the lexicogrammar of many languages in the world. The English element borrowing processes bring a lot of interesting problems viewed from various linguistic perspectives. This paper whose data are collected from several slang dictionaries will try to analyze the use of English borrowings exploited for expressing metaphors in Indonesian intimate speech, widely known as slang. With regards to the metaphorical expressions, the English borrowings that belong to various categories might undergo many kinds of linguistic processes are created to forms conventional and nonconventional metaphors by exploiting various source domains, such as state, action, music and film, food, fruit and animal, friendship and association, human beings and their character, and computer and modern technology. For fulfilling various communicative functions, the slangy expressions are frequently experiencing many kinds of semantic changes.

\section{KEYWORDS}

Borrowing, metaphor, slang, and conventional meaning.

\section{INTRODUCTION}

It is a matter of undeniable fact that English nowadays is the most widely used of language. The speakers of English, either native or nonnative, spread all over the world that directly make all languages in the world are not free from its influence. Accordingly, English elements of all levels, from the lowest up to the highest one, are easily found in the use of world language, and in the use of Indonesian is no exception. In Indonesia, even though English is still considered, as a foreign language, its teaching is already begun from junior high, even in urban areas this language is taught from kinder gardens and preschools. With regards to its influence on the use of Indonesian, the English elements (sound, morpheme, lexeme, lexemic combination, etc) can be found in all styles, from the most formal style up to the least formal one). This paper as suggested by the title, deals with the use of English elements (words or phrases) exploited by Indonesian adolescences for creating metaphorical expressions in the least formal style which is commonly called slang. This issue has not been so far seriously explored by the Indonesian sociolinguists. As a manifestation of creative expressions, the slangy metaphors have several problems that are very interesting to discuss. Those issues at least include these four following issues: forms and categories, types of metaphors, and source domains of metaphorical expressions, and semantic change of the source domain and the target domain.

A lot of linguists have studied this intimate speech style. The authors discusses in length about the characteristics of slang that cover short lived, slippery meaning, marginalized group of the users, oral, and highly conditioned by social situation [1]. Meanwhile, the researchers views the superiority of slang compared to other speech styles that makes the use of it cannot be replaced them [2]. He also states that the use of slang has several functions and its use is motivated by various external factors. The authors investigate the slangy expressions used by youngsters in Jakarta $[3,4]$. Meanwhile, focuses the discussion on intimate speech found in Malioboro Mall, Yogyakarta [5]. More comprehensive studies about Indonesian slang regarding its forms, linguistic formations, origin, and communicative functions have been carried out by $[6,7]$. In more limited scope, the use of English in relation with Indonesian slang can be found in and the use of metaphorical expressions in slangy creations in [8, 9]. This paper will focus its attention on the use of English elements in creating slangy expressions in Indonesian regarding with four issues that has already been mentioned above. This study is considered very important because studies on metaphors so far are rarely related to slangy expressions. For instance, study metaphorical expressions in relation with Indonesian plant names and Indonesian animal names $[10,11]$. The authors respectively associate with metaphorical expressions in crime news story serial and the use of metaphors for approaching meaning $[11,12]$. On The other hand, the newest publication on English slang done by [13] mostly concerns about English slang forms, formulation processes, and their social functions.

The concepts which the human beings are possible to express are unlimited. Unfortunetely, the language elements which is provided to do so are limited. Accordingly, they must express all the possiblly expressed concepts with the readily provided expressions through similarity or association basis. For this purpose, any human language is full of metaphors. According to the researchers [14], metaphor is any linguistic expressions whose meaning can not directly reached by the conventional meaning of that expression, but by its interpretation that hold between the meaning and the expression in specific way. Conceptually, there are three elements in metaphors. Those are something to talk about (target domain), something used to compare (source domain), and the similarity and the association that exsist between them (ground). The pervasive use of metaphors in everyday life both in think and act [15] indicates that metaphorical expressions can be found in all kinds of speech style. Furthermore, the forms and categories used to express, types, and source domains used to compare or concreticize the abstract target domains are also various. Because, the use of language, more specifically metaphors is inseparable from the cultural reality of the speakers owned the language, the use of English elements in Indonesian slangy metaphorical expressions will be more and less influenced by social realities happen in Indonesia.

\section{METHOD}

Metaphorical slangy expressions used as research data are collected from several resources. Those are: 1) Kamus Istilah gaul SMS (Dictionary of SMS Intimacy Terms) by Livia Natalia; 2) Bahasa Baku Vs Bahasa Gaul (Standard Language Versus Slang) by Indari Mastuti; 3) Kamus Gaul Kekinian (The Recent Slang Dictionary) by Ridha Mashudi Wibowo; and 4) Kamus Gaul (Slang Dictionary) by Debby Sahertian. By applying distributional (linguistic) and identity (extralinguistic) method together with their specific techniques, the data are classified according to form and 
category, types of metaphors, source domain, semantic shift, and source domains of the metaphorical expressions.

\section{RESULTS AND DISCUSSION}

The following discussions are the research findings related to the those 4 issues:

\subsection{Forms and Categories}

The metaphorical slang expressions based on the linguistic form can be simply distinghuised into two kinds, i.e word and phrase. The word slangy expressions can further be differentiated into two types: the common word and uncommon word. The common words might constitute monomorphemic words, such as abstract 'ugly', affair 'adultery', absurd 'strange, unclear', etc., or polymorphemic words which constructed through various morphological processes, such as reduplication: ajep-ajep 'gleaming world', blink-blink 'rapper accessories', etc.; affixation, such as Cookies 'a group of excecitve young males' crunchy 'firm and crisp', and Gowes 'goes', etc. Meanwhile, the uncommon words refer to slangy expressions that are constructed through procesess of contraction, such as abbreviation: CT (counter terorist or terrorist counter) to mean 'headquarter', BC (broad cast) to mean 'spread', GG (genetic gals) to mean 'talented sex commercial birls', etc; acronym, such as brownies (brondong manis 'sweet pop corn') to mean 'male or female teenanger'; clipping, such as borju (borjuis) to mean 'rich'; permutation, such as woles (slow) to mean 'relaxed', and compounding such as popcorn to mean 'a rich and hansome male'. Slangy expressions in the form of phrases found in the data collection are ATM Woman (auto machine woman) to mean 'materialistic woman', Body guard 'a friend accompanying to go everywhere', Pentium 1 'out of date computer type' to mean very slow', etc.

Indonesian slangy expressions with English element borrowings cover various kinds of category (part of speech). There are slangs that categorically belong to noun, such as budget the money someone has/brings', affair 'adultery', Caddilac 'drugs', etc.; verb, such as BC 'spread, broad cast', gowes 'goes', hunting 'looking for', loading 'thinking', etc; adjective, such as crunchy 'unfuuny joking', hang 'slow, stupid', mad 'angry, etc. Because the expressions are used informally or inconventionally, there are alot of categorical transposition found in the used of slangs. For instance nouns are used as adjectives: chiken to mean 'coward', pentium 1 to mean 'slow and stupid', etc.; adjectives as nouns: crunchy to mean 'unfunny joking'; autis to mean 'strange person', etc.; nouns as verbs: hiatus to mean 'dissapear', etc.; verbs as noun: gowes to mean 'cycling'.

\subsection{Types of Metaphors}

There are two types of metaphor found regarding the use of metaphors in Indonesian slang. Those are conventional (dead) metaphor and nonconventional (extended metaphor) [7]. Eventhough, the relative difference between these two concepts might still be debatable. Conventional metaphor is one that is used in conventional manner in which no big difference between its literal and metaphorical sense. For instance, in conventional usage, budget is literally used to refer to 'the money that is available to a person or an organization', and in metaphorical meanings it is used to refer to 'the amount of money that someone posses' for exaggerating the expressions. The other examples are $B C$ 'broad cast' to mean 'to spread', abstract 'not having physical reality' to mean 'ugly', affair 'events that are of public interest or political importance' to mean 'love affair, sexual relationship', etc. Unlike conventional metaphor, nonconventional metaphors constitute expressions which contain very different meaning from its literal usage, and this kind of reference is uncommon in the everyday use of language. For example, barbecue has literal meaning 'baked meat yielded from garden party', and it is used metaphorically to mean 'mistress', while for the lawful wife, te slang speakers use sarden 'can sardencis'. Brownies 'brown bread' or its long form brondong manis 'sweet popcorn' is used metaphorically to mean 'rich and handsome young man'. Cadillac 'a large expensive US make of car' in everyday metaphorical use of English is exploited to refer to 'the highest quality of a type of thing', such as in This is the cadillac of watches [16]. However in Indonesian slang, this word is used to mean 'heroin or drugs'. Finnaly, the English word cookies conventionally has a meaning of 'a small flat sweet cake usually baked untill crisp', but in slangy expression is metaphorically used to refer to 'a group of excecutive young males'. Mostly, the extended metaphorical slangy expressions are underlied by the state similarities between the target domains and the source domains. For example, the taste similarity between the barbecue meat and the mistress, between sardencis and the lawful wife. Barbecue meat is considerd much more delicious than can sardencis. The luxury of caddilac and the joyful effect brought by the drugs. In some cases, the similarities is not easy to find, such as between the metaphorical expression jack pot and its metaphorical meaning 'to vomit'.

\section{SOURCE DOMAINS OF THE METAPHORICAL EXPRESSIONS}

There are at least 8 interrelated source domains commonly used as vehicle in creating slangy metaphorical expressions in Indonesian. Those are 1) state, such as autis 'autistic' to mean 'very difficult to communicate or form relationship with others'; borju is created from bourgeois 'the middle class in society' to mean 'very rich' and to be associated with the capitalist; zebb is created from English safe to mean 'alright' etc.; 2) Action, such as gowes created from goes to mean 'cycling', stalking created from crime register to mean 'watching crime move' to mean 'watching ex boy or girl friend'; loading created from computational register 'the amount of work a computer has to do' to mean 'thinking', etc.; 3) music and film, such as ajeb-ajeb 'the imitative sound of disco music' to refer to the discotheque itself, blink-blink 'to open and shut the eyes, to shine with unsteady light' to metaphorically mean 'the assecories of rapper's outfit', Popeye and Spiderman that both literally refer to 'film characters' are used to mean 'muscly little man and spider', etc. 4) food, such as barbecue, cookies, brownies, and sarden are respectively considered having certain similarities with the referents to which they refer, i.e 'mistress', 'young male excecutives', 'young male/female', 'lawful wife', etc.; 5) fruit and animal, such as strawberry and chiken (soup) for certain matters are regarded to have similarity and association with their metaphorical senses, i.e 'woman that wears everything red' and 'coward'. Chiken (soup) is contrasted against fight cock (rooster);6) Friendship and association: such as affair, body guard, hegemony, gang, and night friend that are consecutively metaohorically used to refer to 'friend to go together with', 'club, association', 'friend(s)', and 'prostitute'; 7) Human beings and their character such as Einstein, ATM Woman, Miss Ring-ring, and GG (abbreviation of genetic gals) 'talented women' for metaphorically refering to 'very genius person', 'materialistic woman', 'woman who loke to phone in public place', etc; Computer and modern technology: such as pentium 1 and caddilac to refer to 'slow or stupid' and drugs'. It is noteworthy that loading and hang whose source domain has been classified into action and state are closely related to computer and modern technology.

\section{SEMANTIC CHANGE}

To create metaphorical expressions, the source domains or metaphorical vehicles commonly experience at least four possible semantic changes from their conventional meanings. These changes probably closely relate with the functions of the slangy expressions. The types of the semantic changes are: semantic shifts, semantic association, semantic pejoration, and semantic exaggeration. For example, in order to keep secret any conversation topic to others who do not belong to the slang users' membership, the slang speaker's are often creating slangy expressions having totally different meaning compared to their use in conventional situation, such as the use of cadillac 'car brand' for refering 'drugs' for avoiding the users from police chase; sardencis and barbeque, and browniess are respectively for refering 'lawful wife', 'mistress', and 'younger boy/girl friend'. The semantic change can also be associative in character, such as ATM woman, strawberry, popeye, etc. for methonimically denoting 'materialistic girl', 'woman wearing everything red', and 'muscled little man'. Meanwhile, for expressing insultion, several words might experience semantic pejoration in which the words loose their neutral sense, such as affair, $M L$ and chicken is metaphorically used to mean 'adultery or betrayal', 'sexual intercourse', 'coward', etc. Finally to mock their interlocutors, the slang speakers often exaggrate the meaning the slangy expressions, such as the use of body guard, budget, abstract, autis, etc. for just refering 'friends accompanying some one to go everywhere', 'the amount of money that someone has', 'ugly', 'strange person'.

\section{CONCLUSIONS}

The continously increasing role played by English as an International languages naowadays directly causes that its use is not merely found in formal situations but also in less formal ones, even in very intimate mode of speech, which is familiarly called slang. As far as the Indonesian slangy expressions are concerned, the English borrowings (words or phrases) which categorically belong to various parts of speech (noun, verb, adjective, etc.) are undergoing various linguistic processes, such as abbreviation, contraction, permutation, adaptation, etc. More interestingly, in many cases the English borrowings are used metaphorically for fulfilling various communicative functions, such as exaggrating, mocking, concealing something, and insulting someone. For 
creating metaphorical expressions the borrowings which cover various source domains frequently undergo many kinds of semantic changes, either totally or in part.

\section{REFERENCES}

[1] Amrullah, L. 2017. Slang Bahasa Inggris di Dunia Maya. Yogyakarta: University Press.

[2] Eble, C. 1996. Slang and Sociability: In-Group Language among College Students. Chapel Hill, NC.: University of North Caroline Press.

[3] Hornby, A.S. 2010. Oxford Advanced Learner's Dictionary. Oxford University Press

[4] Lakoff, G., and Mark, J. 1980. Metaphors We Live By. Chicago: The University of Chicago Press.

[5] Lestari, F.W. 2005. Pemakaian Slang Remaja di antara Kaum Jayus dalam Situs Kejayusan di Internet-internet: Sebuah Stdudi Kasus. Tesis Program Pascasarjana. Universitas Gadjah Mada.

[6] Patridge, E. 1954. Slang: Today and Yesterday. London: Routledge \& Kegan Paul.

[7] Pye, C. 2016. A Metaphorical Approach to Meaning". Prosiding Kongres Internasional Masyarakat Linguistik Indonesia. Denpasar. Universitas Udayana.

[8] Rahayu, S. P. 1999. Slang Remaja di Yogyakarta. Studi Kasus di Mall Malioboro. Tesis Program Pascasarjana Universitas Gadjah Mada.

[9] Siregar, B. U. 2016. Metaphors in Crime News Story Serials: A Case Study of The Indonesian Online Detik News. Prosiding Kongres
Internasional Masyarakat Linguistik Indonesia. Denpasar. Universitas Udayana.

[10] Wahab, A. 1995. Metafora sebagai Alat pelacak Sistem Ekologi. Pertemuan Linguistik Lembaga Bahasa Atma Jaya III. Yogyakarta: Kanisius.

[11] Wanter. 1998. Pemakaian Slang di Kalangan Remaja Jakarta. Tesis Program Pascasarjana Universitas Gadjah Mada.

[12] Wijana, I.D.P. 2010a Bahasa Gaul Remaja Indonesia. Malang: PT Aditya Media.

[13] Wijana, I.D.P. 2010. Bahasa Gaul Remaja Indonesia dan Berbagai Persoalannya. Pidato Dies Natalis Fakultas Ilmu Budaya Universitas Gadjah Mada.

[14] Wijana, I.D.P. 2011. The Use of English in Indonesian adolesence Slang. Working paper presented in Language Across Culture Conference. Undiksha. Singaraja Bali.

[15] Wijana, I.D.P. 2015. Source Domains of Indonesian Slangy Metaphorical Expressions. The 4th Graduate Students Conference on English Education, Linguistics, and Literature Proceeding. Sanata Dharma University.

[16] Wijana, I.D.P. 2016. The Use of Metaphors on Indonesian Plant Names. Language, Literature and Society. Harris Hermansyah Setiajid (Ed.). Yogyakarta: Department of English Letters. Universitas Sanata Dharma.

[17] Wijana, I.D.P. 2018. Metaphors of Animal Names in Indonesian. Deskripsi Bahasa. Jurnal Departemen Bahasa dan Sastra fakultas Ilmu Budaya Universitas Gadjah Mada 1(1). 